\title{
Heavy Metal Toxicosis and Male Fertility: The Role of Pentahydroxyflavone Quercetin; a Review
}

\author{
${ }^{* 1}$ SALIHU, SI; ${ }^{1}$ YUSUF, IL; ${ }^{2}$ ABBA, A; ${ }^{1}$ TIJJANI, MB; ${ }^{2}$ MAINA, UA; ${ }^{1}$ SHAMAKI, \\ BU
}

\author{
${ }^{*}$ Department of Veterinary Pharmacology and Toxicology, University of Maiduguri, Nigeria \\ ${ }^{2}$ Veterinary Teaching Hospital, University of Maiduguri, Nigeria \\ *Corresponding Author *Email: sabosalihu83@gmail.com Tel: +2348062487440
}

\begin{abstract}
The effect of heavy metals (HMs) has been extensively studied. They cause diverse clinical manifestation through various mechanisms. Male fertility is among the most disturbing effect of HMs affecting family life in human and reproduction in animals. Notably among these effects is interference with the reproductive hormones, morphology and function of reproductive organs, sexual behaviors, and the spermiogram. Quercetin is a dietary flavanoid from edible plants and, has proven pharmacological properties in the treatment and management of many disease conditions. Quercetin ameliorates the adverse effects of HMs on male reproductive hormones by increasing the activity of $3 \beta$-hydroxysteroid dehydrogenase ( $3 \beta$ -

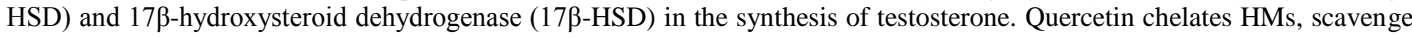
free radicals, and other cytotoxicant capable of disrupting the morphology and function of the male reproductive system. Apart from it neuroprotective activity on the pituitary gland and increased steroidogenesis, quercetin mitigate neurotransmitter that aid in copulation and improve histopathological changes in the brain due to HMs toxicity to improve sexual behavior. Quercetin was also found to be effective in increasing sperm count, daily sperm production, mortility, viability, and also decreased in the percentage of abnormal sperm morphology due to HMs toxicity. In conclusion quercetin was found to be effective in mitigating HMs toxicity that affects male fertility, and so, it is recommended to be incorporated into the treatment and management of HMs toxicity. Individuals who are at risk of HMs toxicity should take dietary plants that contain quercetin to minimize the effects of these metals.
\end{abstract}

\section{DOI:https://dx.doi.org/10.4314/jasem.v25i7.25}

Copyright: Copyright $\odot 2021$ Salihu et al. This is an open access article distributed under the Creative Commons Attribution License (CCL), which permits unrestricted use, distribution, and reproduction in any medium, provided the original work is properly cited.

Dates: Received: 10 May 2021; Revised: 28 June 2021; Accepted: 01 July 2021

Keyword: Fertility, Heavy metals, Quercetin, Toxicant, Health

Heavy metals (HMs) are heterogeneous collection of elements with specific density higher than $5 \mathrm{~g} \mathrm{~cm}^{-3}$ (Martin, and Hosam, 2018). HM are widely distribution in the environment, the toxicity of these metals occur naturally or due to human activities (Arif, et al., 2015), due to their toxic effects in plants, animals, and human, they are considered as common environmental pollutants in the developing world (Cheng, 2003). Exposure to HM mostly occurs inadvertently, in some certain occupations, via inhalation of contaminated air or the consumption of contaminated food and water (Wirth, and Mijal, 2010). Activities such as mining and smelting operation and agricultural production involving these metals have contaminated extensive areas of the world (Herawati et al., 2000). Some HMs such as lead ( $\mathrm{Pb})$, aluminum $(\mathrm{Al})$, mercury $(\mathrm{Hg})$, arsenic (As), and cadmium $(\mathrm{Cd})$ induce toxicity in humans and other living organisms and this toxicity is considered to be mediated through macromolecules such as proteins with structural catalytic or transport function and DNA (Mathur et al., 2010). Clinical manifestation of HMs toxicity varies in a wide spectrum (Sule, et al., 2018). Many HMs can affect multiple organ systems characterized by the involvement of a particular organ (Haschek, and Porpaczy, 1968), others have carcinogenic, growth, and reproductive toxicities (Shestakova et al., 2016). HM may function via hormonal or genotoxic pathways to disrupt male reproduction (Chowdhury, 2009). They may penetrate the blood testicular barrier to potentially affect spermatogenesis, associated with reduced sperm motility and density, increased morphological anomalies, and consequent infertility in males (Mathur et al., 2010). It is not possible to avoid exposure to $\mathrm{HM}$ because of their readily availability in nature and human activities (Wirth and Mijal, 2010; Jahan et al., 2015). Research interest is actively following the characterization of natural products which is not only safe against toxicity caused by HMs but also having health benefits (Kim, et al., 2018). Quercetin, a dietary flavonoid from edible plants such as apple, onion, mulberry, potatoes, broccoli, tea, peanut, soybean, and red wine, it is a potent oxygen free radical scavenger (Jahan et 
al.,2015). Quercetin has many pharmacological properties including antioxidant, neurological, antiviral, anticancer, cardiovascular, antimicrobial, anti-inflammatory, hepatoprotective, anti-obesity, and protection of the reproductive system (Maalik, et al., 2014).

In this review we intend to focus on the reproductive consequence associated with mercury $(\mathrm{Hg})$, lead $(\mathrm{Pb})$, cadmium (Cd), and arsenic (As), how these heavy metals affect male fertility, and the ameleroitive effects of quercetin due to this toxicity in human and animal studies. Using internet search from google scholar, researchgate, scopus and pubMed with keywords such as male fertility, heavy metals, and quercetin.

Mercury: Mercury (Hg) is a HM, it density changes from $13.69 \mathrm{~g} / \mathrm{cm}^{3}$ when liquid to $14.184 \mathrm{~g} / \mathrm{cm}^{3}$ when solid (Simons, 1968). Hg exists in two oxidation states, I and II. Inorganic $\mathrm{Hg}$ (Hg salts) has been found in laxatives, cosmetic products, teething powders, diuretics, and antiseptics (Bjorklunda et al., 2017). $\mathrm{Hg}$ compounds accumulate along the aquatic food chain.Human exposure occurs most commonly through the consumption of seafood (Clarkson, and Magos, 2006), burning of coal and fuel oil (AMAP, 2004). $\mathrm{Hg}$ and its compound exhibited structural and functional alteration of the spermatogenic and leydig cell membrane due to its high affinity towards the hydrolytic enzymes and causing a decrease in ACPase, ATPase, ALKPase resulting to progressive degeneration of peritubular membrane (Roy and Vachhrajani, 1987, 1997). In human studies, high mercury levels have been reported in infertile and subfertile than fertile men (Dickman, and Leung, 1998), the report also indicates exposure to $\mathrm{Hg}$ is associated with tubular atrophy and Sertoli-cell-only syndrome among infertile patients (Keck, et al., 1993). Reproductive toxicity of mercury among various animal studies has been linked with decreased sperm motility, epididymal sperm count, and normal sperm morphology among rats, mice, and monkeys (Mohamed et al., 1987; Homma-Takeda et al., 2001; ). Report on In vitro studies have indicate that $\mathrm{Hg}$ stimulates DNA breaks in spermatozoa (Arabi, and Heydarnejad, 2007), which also decreased sperm motility, dysfunction, and viability of spermatozoa (Mohamed, et al., 1986).

Lead: Lead $(\mathrm{Pb})$ is also a HM with a density of 11.34 $\mathrm{g} / \mathrm{cm}^{3}$ (Thornton et al., 2001). It is the most common industrial metal that has become widespread in air, water, soil, and food. Lead is slightly soluble in water, and is transported mainly through the atmosphere; it deports like calcium in the body and accumulates in bone, liver, kidney, and other tissues (Mukesh, et al.,
2008). Occupational exposure to $\mathrm{Pb}$ toxicity occurs via inhalation of lead-containing specks of dusts and fumes (Gittleman et al. 1994) and the nonoccupational settings, through the consumption of food and drinking water contaminated with $\mathrm{Pb}$ leached lead-containing pipes or from natural geological formations (Wirth and Mijal, 2010). Apart from other toxicity associated with lead (EPA, 2010), it is also considered a male reproductive toxicant (ATSDR, 2007). Pb toxicity occurs through the generation of reactive oxygen species (ROS), displacement of zinc in metal- lothionein (MT) resulting in the alteration of zinc bioavailability and also disrupting blood testicular barrier by replacing calcium in zona adherence junction (Bridges and Zalups, 2005). In a human comparative study, infertile men with low or no sperm or with sperm with low motility had significantly higher mean seminal fluid $\mathrm{Pb}$ levels (mean lead levels $104-150 \mathrm{mg} / \mathrm{L}$ ) compared to men of proven fertility (60mg/L) (Pant et al. 2003). This was demonstrated in a group of Croatian men occupationally exposed with low to moderate $\mathrm{Pb}$ levels (median blood lead $367 \mathrm{mg} / \mathrm{L}$ )were compared to men not occupationally exposed to $\mathrm{Pb}(103 \mathrm{mg} / \mathrm{L})$, their median sperm density, sperm count, and the number of motile sperm were significantly lower in the low to moderately exposed men and also, the blood $\mathrm{Pb}$ was negatively correlated with sperm count $(\mathrm{r}=$ $0.177, \mathrm{p}<0.05)$, progressively motile sperm $(\mathrm{r}=$ $0.179, \mathrm{p}<0.05)$, and positively correlated with abnormalsperm head morphology $(\mathrm{r}=0.209, \mathrm{p}<0.01)$ (Telisman et al. 2000).In an experimental study, the male rats treated with $\mathrm{Pb}$ have an alteration in androgen level with a significant increase in serum follicle stimulating hormone (FSH) and testosterone, however, there was no significant change observed in the level of luteinizing hormone (LH) (Ayinde et al., 2012). Wadi and Ahmad, (1999) investigated Pb toxicity in male reproductive system of sexually mature male $\mathrm{CF}-1$ mice by administering two concentrations of $\mathrm{Pb}(0.25 \%$ and $0.5 \%)$ via drinking water for 6 weeks. It was observed that the low $\mathrm{Pb}$ dose significantly reduced the number of sperm within the epididymis, while the high dose reduced both the sperm count and percentage of motile sperm and increased the percentage of abnormal sperm within the epididymis. Plasma androgen levels were not affected by $\mathrm{Pb}$ administration indicating that lead targets testicular spermatogenesis and sperm within the epididymis to produce reproductive toxicity rather than acting at other sites within the hypothalamicpituitary-testicular axis.

Cadmium: Cadmium (Cd) is a HM with a density of $8.69 \mathrm{~g} \mathrm{~cm}^{-3}$ and oxidative state of $2^{+}$(Haynes, 2015). Cadmium is one of the HMs that occurs 
naturally at low concentrations, commonly associated with ores of zinc, lead, and copper (Wirth and Mijal, 2010). Natural sources of Cd include weathering of rocks, volcanic activity, sea aerosols, forest fires, and gathering from soils, and landfills (Ekaterina and Nina 2018). Cd toxicity occurs through inhalation and ingestion mainly from nickel-cadmium batteries, pigments in paints, chemical stabilizers, metal coatings, alloys, pesticides and fertilizers. Other sources of $\mathrm{Cd}$ poisoning includes photovoltaic devices, rubberprocessing, galvanization process, fossil combustion and waste incineration (Anju et al., 2014). Following absorption, $\mathrm{Cd}$ is predominantly deposited inthe liver and kidney, which is considered a critical target of its toxicity (Rafati et al., 2017). Workers in the metal refining industries that handle $\mathrm{Cd}$ have been shown to suffer from ailments such as damaged lungs, gastric disorders, bone fracture, reproductive failure, infertility, and damage of the central nervous system, psychological disorder, DNA damage, or development of cancer among others (Singh, et al., 2007). The most hazardous effect of $\mathrm{Cd}$ is its ability to accumulate in the body systems throughout alifetime due to its long biological half-life (Hideaki et al. 2008). The toxicodynamics of $\mathrm{Cd}$ includes, interference with DNA repair mechanism, production of ROS, induction of apoptosis, binding to mitochondria, and inhibition of both cellular respiration, and oxidative phosphorylation at low concentration (Rani et al., 2014). The Agency for Toxic Substances and Disease Registry (ATSDR), established there was inadequate data to ascertain the effects of inhaled $\mathrm{Cd}$ on reproductive outcomes in human (ATSDR 2008). However, results from several studies conducted to assess the effects of its low exposure in humans and in various species of mammals, have provided some facts in support of its effect on some male reproductive indices (Wirth and Mijal, 2010; Marettov et al., 2015). In humans, the effect of $\mathrm{Cd}$ on the male reproductive system is agedependent and, also dose and time dependent with many effect elevated after the fourth decades of life (Oldereid et al.,1993;). Smoking of cigarettes containing $\mathrm{Cd}$ has been associated with a decrease in testicular size (Jurasovic et al., 2004) which is associated with low sperm count due to apoptosis of sperm cells (Chia et al., 1994). Telisman et al. (2000) report that there were significant positive correlations between blood $\mathrm{Cd}$ levels and pathologic sperm ( $\mathrm{r} 1 / 4$ $0.158, \mathrm{p}<0.05)$, and leutinizing hormone $(\mathrm{r} 1 / 40.158$, $\mathrm{p}<0.05)$ and testosterone $(\mathrm{r} 1 / 40.1295, \mathrm{p}<0.01)$ levels and a negative correlation with prolactin level (r $1 / 4$ $0.168, \mathrm{p}<0.05$ ) among 98 industrial workers (median blood $\mathrm{Cd}$ level $3.40 \mathrm{mg} / \mathrm{L}$ ) and 51 subjects not occupationally exposed (median Cd level $1.83 \mathrm{mg} / \mathrm{L}$ ) . In animal in-vitro studies, $\mathrm{Cd}$ affect male reproduction from embryonic to adult stage, with an adverse effect on the development of the gonads (Thompson and Bannigan, 2008). Tam and Liu, (1985) report subfertility and aberrant maturation of gametes due to the administration of $\mathrm{Cd}$ to mouse embryo. $\mathrm{Cd}$ readily crosses the testicular blood- barrier and cause a reduction in germ cells numbers which lead to infertility due to disruption of the blood-testis barrier, testicular necrosis and dystrophy as well as a decrease in the plasma testosterone level (Chung and Cheng, 2001). A Study on the intraperitoneal administration of $\mathrm{Cd}$ to adult rats for 16 days indicates a decrease in the volume and viability of cauda epididymis sperm, the quantity of free serum testosterone, cell proliferation, and Johnsen Scores in the seminal tubules (Yari et al., 2016). In vitro addition of $\mathrm{Cd}$ to Sertoli cell culturesandspermatocytes facilitate the mean of entry into cells due to its ability to disrupt the occludin junctions between cells. (Chung and Cheng 2001; Siu et al., 2009). Once Cd enters into a cell, it causes cellular damage which has been attributed mainly to its interference with zinc mediated metabolic processes (Bridges and Zalups 2005), indirectly increases levels of ROS, and induce oxidative stress (Valko et al., 2005) leading to lipid peroxidation (El-Demerdash et al., 2004), and also increase the level of apoptotic biomarkers (Thompson and Bannigan 2008).

Arsenic: Arsenic (As) appears in three allotropic forms: yellow, black and grey; the stable form is a silver-gray, brittle crystalline solid. It tarnishes rapidly in air, and at high temperatures burns to form a white cloud of arsenic trioxide. Arsenic is a HM with a density of $5.7 \mathrm{gcm}^{-3}$ (Wirth Mijal, 2010). Arsenic poisoning occurs through inhalation, skin absorption and, primarily, by ingestion of contaminated food and water (Ratnaike, 2003). Natural exposure to arsenic toxicity includes trace quantities in rock, soil, water, and air and anthropogenic activities such as metal mining and smelting, fossil fuel combustion, sawdust or smoke from wood treated with arsenic, toxic waste sites, and traditional medicines (Naujokas et al., 2013). As and its compounds are exploited productively in pharmaceutical, agriculture, mining, and glass-making industries for centauries (Hughes et al., 2011). As is desired for the safeguarding of dietary, and health conditions of humans at low dosage (Renu, et al., 2018). Contamination with As causes various health challenges such as cancer (Chayapong, et al., 2017), cardiovascular diseases (Chiou et al., 1997), diabeticpathophysiology (Renu, et al., 2017), and reproductive toxicity (Kim and Kim, 2015). Toxicity due to As involved inactivation of up to 200 enzymes, most commonly those associated with cellular energy pathway, DNA replication and repair, 
substitution of phosphate in high energy compounds such as ATP and generation of ROS that cause lipid peroxidationand DNA damage (Cobo and Castineira, 1997; Abernathy, et al.,1999).Epidemiological observational studies in humans exposed to As has been linked to reproductive dysfunction in males through a reduction in testicular weight, accessory sex organ weight, viability, and motility of sperm, epididymal sperm count, decreased gonadotrophins level, decreased testosterone, and steroidogenesis (Renu, et al., 2018). A report by a Chinese cohort study, indicate positive correlation between As concentration and decreased sperm concentration due to environmental exposure of 96 males with an age range between 32 and 36 years to $\mathrm{As}$ (Xu, et al., 2012). In a similar study, the exposure of $\mathrm{As}>50 \mathrm{ppb}$ in drinking water to males in Taiwan (177 in number, age $\geq 50$ years), indicates increased risk of erectile dysfunction with reduced circulating testosterone level (Hsieh, et al., 2008). Animal and In-Vitro Studies; Sudha, (2012), reported that As caused the reduction in antioxidant enzymes by increasing oxidative stress, and this was corroborated by the damages of the sperm DNA and instability in nuclear constituents(Rajesh et al., 2002). The administration of $5 \mathrm{mg}$ sodium arsenite/kg body weight for 12 weeks to Teddy buck goat caused a significant reduction in sperm count, motility, and male reproductive hormones (Zubair et al., 2016). Male rats exposed to sodium arsenite at 5 $\mathrm{mg} / \mathrm{L}$ for 4 weeks in drinking water also resulted in decreased testicular weights, accessory sex organ weights, and epididymal sperm counts, as well as extensive degeneration of a wide variety of germ cells at stage VII of the spermatogenic cycle (Jana et al., 2006). Administration of sodium as orally at the dose of $0.4 \mathrm{ppm}$ to pregnant and lactating mice, resulted in a reduction in spermatogenesis and steroidogenesis in the next generation of adult mice (Reddy et al., 2011). Lin et al. (2002), also reported a reduced sperm motility and fertilization in inseminated semen with increased malondialdehyde (MDA) concentration in testicular tissue of Ducks exposed to $1.2 \mathrm{ppm}$ as trioxide for 8 weeks.

Ameliorative effect of quercetin on HMs induced reproductive toxicity in males: Some of those key factors that serve as indices for the evaluation of male fertility are: male reproductive hormones, morphology, and function of the reproductive organs, sexual behavior, and spermiogram. These are discussed in the following context considering the impact of HMs toxicity on male's fertility and how quercetin possibly mitigate these effects.

Male reproductive hormones: Reproductive function in male is mediated by different hormones (Sengupta and Arafa, 2019). The hypothalamopituitarygonadal/testicular axis also known as the 'master' regulator hormonal axis is led by the pulsatile release of a hypothalamic gonadotropic releasing hormone $(\mathrm{GnRH})$. This, in turn, stimulates the anterior pituitary trophic hormones, the leutinizing hormone (LH) and follicular stimulating hormones (FSH) which act upon the testicular cells, the Leydig cells for steroidogenesis, and Sertoli cells to aid spermatogenesis, respectively (Dutta et al., 2019). Some of these HMs as mention earlier are capable of interfering with reproductive hormone, and invariably affect fertility (Sokol et al., 1985; Laskey and Phelps 1991; Jahan et al., 2015). In an experimental study, coadministration of quercetin with sodium arsenites, yielded a significant increase in serum, and intratesticular testosterone (Ciftci et al., 2012; Jahan 2015), this suggest the supplementation of quercetin serves to attenuate the adverse effects of As intoxication by inhibiting ROS and reactive nitrogen species (RNS) generation in increasing testosterone level (Jahan et al., 2015). The enzymes 3 $\beta$ hydroxysteroid dehydrogenase (3 $\beta$-HSD) and $17 \beta$ hydroxysteroid dehydrogenase (17 $\beta$-HSD) are important enzymes required for steroidogenesis, they are involved in the biosynthesis of the substrate cholesterol to testosterone (Abarikwu and Farombi, 2014). Cds compounds decreased the activities of $3 \beta$ HSD and 17 $\beta$-HSD leading to increased testicular cholesterol concentration with the corresponding decrease in testosterone concentration (Sadik, 2008). Ujah et al., (2017), reported that quercetin attenuates negative changes in rats experimentally induce with $\mathrm{CdCl}_{2}$ by improving the suppressed steroidogenesis, penile erection, and sexual behavior. In a similar study, the increase intra-testicular concentration of testosterone was observe in quercetin plus As treated rats, this may be possible due to quercetin inducing androgenic enzyme activity (Jahan et al., 2015).

Morphology and function of reproductive organs: The male reproductive system is divided into primary, and secondary reproductive organs. Primary reproductive organs include the gonads (responsible for gamete and hormone production), while the secondary organs include the ducts and glands, which play an important role in the growth, maturation, and transmission of gametes (Ampatzidis et al., 2019). Heavy metals toxicosis interfere with the morphology, and functions of these organs, by inhibiting the protective mechanism against free radicals and other cytotoxic mechanisms (Kanter et al., 2016) thereby affecting fertility (Mathur, et al., 2010). Pant et al., (2004) report a decrease in absolute and relative testicular weight due to the administration of sodium arsenites via drinking water at the dose of $4 \mathrm{ppm}$ day- ${ }^{1}$ for 365 
days in the mouse. Sarkar et al., (2003) also a report similar findings with a relative decrease in testicular weight, seminiferous tubular diameter, gametogenic cell population with atrophy of the leydig cells observed in dose-dependent manner due to subchronic administration of sodium arsenic at 30 and 40 $\mathrm{mg} \mathrm{L}^{-1}$ via drinking water to mice (Sarkar et al., 2003). Ragan and Mast (1990) in a human study, report testicular necrosis due to occupational exposure to $\mathrm{Cd}$. Acute intraperitoneal administration of lead nitrate $\left(\mathrm{PbNO}_{3}\right)$ at 50, 25, and $12.5 \mathrm{mg} \mathrm{kg}^{-1} \mathrm{~b} . \mathrm{wt}$, increase the incidence of apoptosis in spermatogenic cells, and germinal epithelium with empty spaces (Massanyi et al., 2007). Previous studies also indicate quercetin ameliorate HMs toxicity by chelation and scavenge free radicals and other cytotoxicants (Bros, et al., 1990; Anjaneyulu, and Chopra, 2004; Ravichandran et al., 2014).These protective effects of quercetin in HMs toxicoses affecting the morphology, and function of the males reproductive system may be attributed to it proliferative capacity, increase in the tubular epithelial height and sperm number (Jahan et al., 2015).

Sexual behavior:Male normal sexual function is characterized primarily by the erection of the penis and ejaculation, however, persistent absence of these hallmarks could be referred to as male sexual dysfunction (MSD) (Guay et al., 2003). MSD could manifest as a lack of desire, persistent delay in/absence of orgasm, erectile dysfunction, quick ejaculation, and priapism (Yakubu and Akanji, 2011). These among other causes of MSD are associated with HMs toxicoses (Ujah et al., 2017). Research findings have indicated that neurotransmitters such as norepinephrine (NE), dopamine and nitric oxide (NO) are involved in sexual behavior and performance in male (Mokhtari, and Zanboori, 2001). Dopamine participates in the dopaminergic system that is involve in the regulation of cognition and triggers penile erection by acting on oxytocinergic neurons located in the paraventricular nucleus of the hypothalamus, and perhaps on the pro-erectile sacral parasympathetic nucleus within the spinal cord (Giuliano, and Allard, 2001). Previous work demonstrates HMs inference with dopamine (Lafuente et al., 2005; Fang-I, et al., 2008). NO is an atypical regulatory molecule that acts as a second messenger and a neurotransmitter, it is synthesized via the stimulation of the enzyme nitric oxide synthase (NOS),it has been implicated in diverse physiological activities including mediator of male sexual behavior (Forstermann et al., 1990;). NO, mediate penile erection by inhibiting smooth muscle of the corpora cavernosa, thereby allowing vasodilation of the corpora, but it increased the number of ex copula seminal emissions and decreased the latency to the first seminal emission which helps prevent premature ejaculation (Hull et al., 1994). NO synthesis and biochemical functions are affected by HMs (Kumagai, and Pi, 2004; Jennrich, 2013). Sexual behavior is also affected by HMs via interference with the $\mathrm{GABA}_{\mathrm{A}}$ receptors in the production of adrenal, and gonadal steroids (Iavicoli et al., 2008). As mentioned earlier HMs are also capable of causing oxidative stress and brain damage which possibly affect sexual behavior due to altered spatial memory and locomotor activities. (Nageshwar et al., 2019). Marked impairment in sexual activity, territorial aggressive behavior and anxiety- like behavior was observed in males Wistar rats exposed to $\mathrm{CdCl}_{2}$ (Mervat et al., 2011). Also, Mokhtari and Zanboori (2011) report similar findings in rats exposed to lead acetate. Sharma et al., (2018) in an experimental study, observed the protective activity of quercertin on the pituitary gland, and increased in steroidogenic enzymes 3ß-HSD and 17ß-HSD, responsible for enhanced biosynthesis of testosterone. It has also been documented that quercetin has neuroprotective efficacy in progressive dopaminergic neurodegenerative MitoPark transgenic mouse model of Parkinson's disease (Muhammet et al., 2017). According to Nageshwar et al., (2019), quercetin abrogates histopathological alterations in the brain, ameliorates motor coordination, and decreased the latency period against sodium arsenate induced behavioural deficit in the rat.

Spermiogram: The spermiogram serves as a basis for the diagnosis of possible fertility problems in males. It involves the assessment of various characteristics of the ejaculatory fluid (semen). However, the most important characteristics considered for the analysis of the ejaculate are; Quantity, $\mathrm{pH}$ level, Sperm concentration (in million sperm $/ \mathrm{ml}$ ), Morphology (percentage of normally formed sperm cells), and motility (movement, expressed as a percentage). (https://www.kinderwunschteam.berlin/en/infertility/ diagnostik/diagnostik spermiendiagnostik/). Human and animal evidence suggests that HMs may have adverse impacts on male reproductive health at relatively low levels with semen quality (Meeker et al., 2008). These metals are also found in seminal plasma of individuals exposed to theses toxicants which may be poor indicators of andrological parameters (Hovatta, et al., 1998). For example, Cd has been linked to poor semen quality, and DNA damage in humans, and animals' studies (Telisman et al. 2000; $\mathrm{Xu}$ et al., 2003). $\mathrm{Pb}$ adversely affects the shape of the spermatozoa, its motility, and DNA integrity (Eibensteiner et al. 2005). Xu, et al., (2012) report a decrease in sperm count, viability and motility due to as toxicity. Previous studies also reveal $\mathrm{Hg}$ toxicities affect semen quality (Mohamed, et al., 1986; 
Choy et al. 2002). Al-Omair et al., (2017) in an experimental study, report significant increase in sperm count, motility, and a decrease in percentage of abnormal sperm in rats co-treated with lead, and quercetin compared with lead acetate treated group. Also, in a similar study, Jahan et al., (2015) report quercetin was found to be effective against as induced reduction of daily sperm production and DNA damage. Abnormal changes observed in spermiogram due $\mathrm{Cd}$ toxicity were reverse to near normal in quercetin co-treatment, thus indicating ameliorative activities of these compounds (Farombi, et al., 2012). It was also reported that quercetin protects both goat sperm and preimplantation embryos from $\mathrm{Cd}^{2+}$ induced oxidative stress (Mao et al., 2018).

Conclusion: Unrestrained industrialization and urbanization without proper emission controls of HMs disposal are the attributable factors that have exposed human lives to risk of infertility in males. Quercetin apart from its other pharmacological activities is proven to ameliorate HMs toxicity affecting male fertility. Consumption of dietary food rich in quercetin may be of benefit most especially in individuals at high risk of HMs toxicity, and thus, could be of clinical usefulness in the management and treatment of these environmental toxicants.

\section{REFERENCE}

Abarikwu, SO; Farombi, EO (2014). Quercetin ameliorates atrazineinduced changes in testicular function of rats. Toxicol. Ind Health. 32(7): 12781285 .

Abernathy, CO; Liu, YP; Longfellow, D (1999).Arsenic: health effects, mechanisms of actions, and research issues. Environ Health Perspect 107: 593-7

Al-Omair, MA; Sedky, A; Ali, AA; Elsawy, H (2017). Ameliorative Potentials of Quercetin against LeadInduced Hematological and Testicular Alterations in Albino Rats. Chin J Physiol. 60(1): 54- 61

AMAP. Oslo; Arctic Monitoring and Assessment Programme (AMAP); 2004. AMAP Assessment 2002: Heavy metals in the Arctic.

Ampatzidis, G; Georgakopoulou, D; Kapsi, G; Clitoris, J (2019). The unknown: what do postgraduate students of educational sciences know about reproductive physiology and anatomy? $J \quad$ Biol Educ. doi:10.1080/00219266.2019.1679658
Anjaneyulu, M; Chopra, K (2004). Quercetin, anantioxidant bioflavonoid, attenuates diabeticnephropathy in rats. Clin. Exp. Pharmacol. Physiol., 31: 244-248.

Anju, R; Anuj, K; Ankita, L; Manu, P (2014). Cellular mechanisms of cadmium-induced toxicity: a review.Int J Environ Health Res. 24(4): 378-399. Arabi, M; Heydarnejad, MS (2007).In vitro mercury exposure on spermatozoa from normospermic individuals. Pak J Biol Sci. 10(15):2448-53

Arif, TJ; Mudsser, A; Kehkashan, S; Arif, A; Inho, C; Qazi, MRH (2015). Heavy metals and Human Health: Mechanistic Insight into Toxicity and Counter Defense System of Antioxidants. Int. J. Mol. Sci.16, 29592-29630

ATSDR. (2007). Toxicological Profile for Lead. Ed. UDoHaHS Agency for Toxic Substances and Disease Registry. US Department of Health and Human Services. Public Health Service, Atlanta, GA, USA

ATSDR. (2008). Toxicological profile for Cadmium (Draft for Public Comment). U.S. Department of Health and Human Services. Public Health Service, Atlanta, GA, USA

Ayinde, OC; Ogunnowo, S; Ogedegbe, RA (2012). Influence of Vitamin $\mathrm{C}$ and Vitamin $\mathrm{E}$ on testicular zinc content and testicular toxicity in lead exposed albino rats. BMC Pharmacol. Toxicol.13, 17

Bjorklunda, G: Dadarb, M; Mutterc, J; Aasethd, J (2017). The toxicology of mercury: Current research and emerging trends. Environ. Res. 159: $545-554$.

Bridges, CC; Zalups, RK; (2005). Molecular and ionic mimicry and the transport of toxic metals. Toxicol Appl. Pharmacol. 204:274-308

Bros, W., Heller, W., Michel, C. and Saran, M. 1990. Flavonoids as antioxidants: determination of radical-scavenging efficiencies. Methods Enzymol. 186: $343-355$

Chauhan, V., Srikumar, S., Aamer, S., Pandareesh, M.D. and Chauhan, A. 2017. Methylmercury Exposure Induces Sexual Dysfunction in Male and Female Drosophila Melanogaster. Int J Environ Res Public Health. 14(10):1108 
Chayapong, J; Madhyastha, H; Madhyastha, R.; Nurrahmah, QI; Nakajima, Y;Choijookhuu, N; Hishikawa, Y; Maruyama, M (2017). Arsenic trioxide induces ROS activity and DNA damage, leading to a G0/G1 extension in skin fibroblasts throughthe ATM-ATR-associated Chk pathway. Environ. Sci. Pollute. Res. Int. 24 5316-5325

Cheng, SP (2003). Heavy metals pollution in China: Origion, pattern and control. Environ. Sci. Pollute. Res. Int. 10: 192-198.

Chia, S; Xu, B; Ong, CN; Tsakok, FM Lee, ST (1994). Effect of cadmium and cigarettesmoking on human semen quality. Int J FertilMenopausal Stud. 39(5): 292

Chiou, HY; Huang, WI; Su, CL (1997).Dose-response relationship between prevalence of cerebrovascular disease and ingested inorganic arsenic. Stroke. 28:1717-23

Chowdhury, AR (2009). Recent advances in Heavy metals induced effect on male reproductive function-A retrospective. Al Ameen J. Med. Sci. 2: 37-42.

Choy, CM; Yeung, QS; Briton-Jones, CM; Cheung, CK; Lam, CW; Haines, CJ (2002). Relationship between semen parameters and mercury concentrations in blood and in seminal fluid from subfertile males in Hong Kong. Fertil Steril. 78(2): 426-8.

Chung, NP; Cheng, CY (2001). Is Cadmium Chloride Induced Inter-Sertoli Tight Junction Permeability Barrier Disruption a Suitable in Vitro Model to Study the Events of Junction Disassembly duringSpermatogenesis in the Rat Testis? Endocrinology: 142(5): 1878-1888

Ciftci, O; Aydin, M; Ozdemir, I; Vardi, N (2012). Quercetin prevents 2,3,7,8-tetracholorodibenzo-pdioxin-induced testicular damage in rats. Androlog. 44:164-73

Clarkson, TW Magos, L (2006). Review: The toxicology of mercury and its chemical compounds.Crit Rev Toxicol. 36(8):609-62.

Cobo, JM; Castineira, M (1997). Oxidative stress, mitochondrial respiration, and glycemic control: clues from chronic supplementation with $\mathrm{Cr} 3+$ or As3+ to male Wistar rats. Nutrition. 13: 965-70
Dickman, MD; Leung, KM (1998). Mercury and organ chlorine exposure from fish consumption in Hong Kong.Chemosphere. 37(5):991-1015.

Dutta, S; Sengupta, P; Muhamad, S (2019). Male reproductive hormones and semen quality. Asian Pac J Reprod. 8(5): 189-194.

Eibensteiner, L; Sanz, ADC; Frumkin, H; Gonzales, C; Gonzales, GF; (2005). Lead exposure and semen quality among traffic police in Arequipa, Peru. Int J Occup. Environ Health. 11(2):161-6

Ekaterina, P; Nina, A (2018).Impact of Cadmium on Male Fertility. Acta morphologica et anthropologica. 25 (1-2): 108- 116

El-Demerdash, FM; Yousef, MI; Kedwany, FS; Baghdadi, HH (2004). Cadmium-induced changes in lipid peroxidation, blood hematology, biochemical parameters and semen quality of male rats: protective role of vitamin $\mathrm{E}$ and beta-carotene. Food Chem Toxicol.42:1563-1571

EPA (2010). An overview of Airborne Metal Regulations, Exposure Limits, Health Effects and Contemporary Research (Appendix C). Available online: http://www3.epa.gov/ttnemc01/prelim/ otm31 appC.pdf (accessed on 2 October 2015).

Fang-I, H; Ti-Sheng H; Yi-Chen, H; Hsiu-Chiung, L; Chien-Tien S; Hui-Shing, H; Hung-Yi C; ChienJen C(2008). Risk of Erectile Dysfunction Induced by Arsenic Exposure through Well Water Consumption in Taiwan. Environ Health Perspect. 116(4): 532-536

Farombi, EO; Adedara, IA; Akinrinde, SA; Ojo, OO; Eboh. AS (2012). Protective effects of kolaviron and quercetin on cadmium-induced testicular damage and endocrine pathology in rats. Andrologia. 44(4):273- 284.

Forstermann, U; Gorsky, LD; Pollock, JS; Schmidt, HHHW; Heller, M; Murad, F (1990). Regional distribution of EDRF/NO-synthesizing, Biochem. Biophys. Res. Commun. 168. 727.

Gittleman, JL; Engelgau, MM; Shaw, J; Wille, KK; Seligman, PJ (1994). Lead poisoning among battery reclamation workers in Alabama. J Occup Med. 36:526-532

Giuliano, F; Allard, J. (2001). Reviw: Dopamine and sexual function. Int J Impot Res.13 (3):18-28. 
Guay, AT; Spark, RF; Bansal, S; Cunningham, GR; Goodman, NF; Nankin, HR; Perez, JB (2003). American Association of Clinical Endocrinologists Medical Guidelines for Clinical Practice for the evaluation and treatment of male sexual dysfunction: A couple's problem. Endocrine Practice. 9 (1): 77-95

Haschek, H; Porpaczy, P; (1968). Therapeutic and toxicologic problems in the therapy of nonspecific urinary tract infections with impaired kidney function. Wien KlinWochenschr. 80(42):769-76

Haynes, WM (2015). CRC Handbook of Chemistry and Physics, CRC Press/Taylor and Francis, Boca Raton, FL, 95th Edition, Internet Version 2015, accessed December 2014.

Herawati, N; Susuki, S; Hayashi, K; Rivai, IF; Koyama, H (2000) Bulletin of Environmental Contamination and Toxicology. 64: 33-39

Hideaki, S; Yasutake, A; Hirashima, T; Takamure, Y; Kitano, T, Waalkes, MP; Imamura, Y (2008). Strain difference of cadmium accumulation by liver slices of inbred Wistar-Imamichi and Fischer 344 rats. Toxicol In Vitro. 22:338-343.

Homma-Takeda, S; Kugenuma, Y; Iwamuro, T; Kumagai, Y; Shimojo, N (2001). Impairment of spermatogenesis in rats by methylmercury: involvement of stage- and cell- specific germ cell apoptosis.Toxicology. 169(1):25-35.

Hovatta, O; Venalainen, ER; Kuusimaki, L; Heikkila, J; Hirvi, T; Reima, I (1998). Aluminium, lead and cadmium concentrations in seminal plasma and spermatozoa, and semen quality in Finnish men. Human Reproduction. 13 (1): 115-119

Hughes, MF; Beck, BD; Chen, Y; Lewis, AS; Thomas, DJ (2011). Arsenic exposure and toxicology: a historical perspective. https://doi.org/10.1093/toxsci/kfr184.

Hull, EM; Lumley, LA; Matuszewich, L; Dominguez, J; Moses, J; Lorrain, DS (1994). The Roles of Nitric Oxide in Sexual Function of Male Rats. Neuropharmncolog. 33(11): 1499-I 504

Hsieh, F-I; Hwang, T-S; Hsieh, Y.-C; Lo, H-C; Su, CT; Hsu, H-S; Chiou, H-Y; Chen, C-J (2008). Risk of erectile dysfunction induced by arsenic exposure through well water consumption in Taiwan,
Environ. Health Perspect. $116 \quad$ 532, https://doi.org/10.1289/ehp.10930.

Iavicoli, I; Fontana, L; Bergamaschi, A (2009). The Effects of Metals as Endocrine Disruptors. J Toxicol Environ Health B Crit Rev. 12(3): 206-223

Jahan, S; Iftikhar, N; Ullah, H; Rukh, G; Hussain, I (2015). Alleviative effect of quercetin on rat testis against arsenic: a histological and biochemical study. Syst Biol Reprod Med. 61(2): 89-95

Jana, K; Jana, S; Samanta, PK; (2006). Effects of chronic exposure to sodium arsenite on hypothalamo-pituitarytesticular activities in adult rats: Possible an estrogenic mode of action. Reprod Biol Endocrinol. 16:4-9.

Jennrich, P (2013). Review Article The Influence of Arsenic, Lead, and Mercury on the Development of Cardiovascular Diseases. ISRN Hypertension. http://dx.doi.org/10.5402/2013/234034

Jurasovic, J; Cvitkovic, P; Pizent, A (2004). Semenquality and reproductive endocrine function withregard to blood cadmium in Croatian malesubjects. Biometals. 17(6): 735-743.

Kanter, M; Aktoz, T; Aktas, C; Ozen, F; Yarali, O; Kanter, B (2016). Role of quercetin in cadmiuminduced oxidative stress, testicular damage, and apoptosis in rats. Anal Quant Cythopathol Histopathol. 38(1), 45-51.

Keck, C; Bergmann, M; Ernst, E; Muller, C; Kliesch, S; Nieschlag, E (1993). Autometallographic detection of mercury in testicular tissue of an infertile man exposed to mercury vapor.Reprod Toxicol. 7(5):469-75.

Kim, Y-J, Kim, J-M (2015). Arsenic toxicity in male reproduction and development. Dev. Reprod. Biol. 19: 167-180Kim, JH; Kismali, G; Gupta, SC (2018). Natural Products for the Prevention and Treatment of Chronic Inflammatory Diseases: Integrating Traditional Medicine into Modern Chronic Diseases Care. Evidence-Based Complementary and Alternative Medicine., https://doi.org/10.1155/2018/9837863

Kumagai, Y; Pi, J (2004). "Molecular basis for arsenic-induced alteration in nitric oxide production and oxidative stress: implication of endothelial dysfunction. Toxicol Appl. Pharmacol. 198(3):450-457 
Lafuente, A; Gonzalez-Carracedo, A; Romeroa, A; Cabaleiroa, T; Esquifinob, AI (2005). Toxic effects of cadmium on the regulatory mechanism of dopamine and serotonin on prolactin secretion in adult male rats. Toxicol Lett. doi:10.1016/j.toxlet.2004.08.011

Laskey, JW; Phelps, PV (1991). Effect of cadmium and other metal cations on in vitro Leydig cell testosterone production. Toxicol Appl Pharmacol. 108:296-306

Lin, CC; Huang, CC; Chen, MC; Huang, JF; A; Chiou, HY (2002).Arsenic toxicity on duck spermatozoa and the ameliorating effectof Lascorbic acid. AJAS. 15:19-25

Maalik, A; Farhan, AK; Amara, MAM; Saira, A; Muhammad; A; Sabiha, K; Yasir, A; Imran, T (2014). Pharmacological Applications of Quercetin and its Derivatives: A Short Review. Trop J Pharm Res, 13(9): 1561.

Manna, P; Sinha, M; Sil, PC; (2008). Cadmium induced testicular pathophysiology: Prophylactic role of taurine. Reproductive Toxicology. 26: 282 291

Mao, T; Han, C; Wei, B;, Zhao, L; Zhang, Q; Deng, R; Liu, J; Luo, Y; Zhang, Y (2018). Protective Effects of Quercetin Against Cadmium ChlorideInduced Oxidative Injury in Goat Sperm and Zygotes. Biol Trace Elem Res 185: 344-355

Marettov, E; Maretta, M; Legáth, J (2015). Toxic effects of cadmium on testis of birds and mammals: a review. - Animal reprod sci. 155: 1-10.

Martin, K; Hosam, MS; (2018). Introductory Chapter: Introducing HM, HM, Hosam El-Din M. Saleh and Refaat F. Aglan, IntechOpen, DOI: 10.5772/intechopen.74783.

Massanyi, P; Lukaa, N; Zemanosova, J; Makarevich, AV; Chrenek, P (2007). Lead- induced alteration in rat kidney and testes in vivo. J. Toxicol. Environ. Sci. Health. 42:865-870

Mathur, N; Pandey, G; Jain, GC (2010). Male Reproductive Toxicity of Some Selected Metals: A Review. J. Biol. Sci. 10 (5): 396-404.

Meeker, JD; Rossano, MG; Protas, B; Diamond, MP; Puscheck, E;, Daly, D; Paneth, N;. Wirth, JJ (2008). Cadmium, Lead, and Other Metals in Relation to Semen Quality: Human Evidence for Molybdenum as a Male Reproductive Toxicant.
Environmental Health Perspect. 116 (11). 14731479

Mervat, MK; Abeer, HAE; Kawkab, AA; Gehan, MK; (2011). Exposure of Adult Male Rats to Cadmium: Assessment of Sexual Behaviour, Fertility, Aggression as well as Anxiety like Behaviour with Special Reference to Biochemical and Pathological Alterations. Life Sci 8(2):106-119

Mohamed, MK; Burbacher, TM; Mottet, NK (1987). Effects of methyl mercury on testicular functions in Macaca fascicularis monkeys.Pharmacol Toxicol. 60(1):29-36.

Mohamed, MK; Lee, WI; Mottet, NK; Burbacher, TM (1986). Laser light-scattering study of the toxic effects of methylmercury on sperm motility.J Androl. 7(1):11-5.

Mokhtari, M; Zanboori, M(2011).The Effect of Lead Acetate on Sexual Behavior and Level of Testosterone in Adult Male Rats. Int J fertil steril. 5 (1): $13-20$

Muhammet, A; Luo, J; Langley, M; Jin, H; Anantharam, V; Kanthasamy, A; Kanthasamy, AG. (2017). Molecular mechanisms underlying protective effects of quercetin against mitochondrial dysfunction and progressive dopaminergic neurodegeneration in cell culture and MitoPark transgenic mouse models of Parkinson's

Disease. https://doi.org/10.1111/jnc.14033

Mukesh, KR; Puneet, K; Manoj, S; Anand, S (2008). Review: Toxic effect of Heavy metals in livestock. Veterinary World: 1(1):28-30

Nageshwar, M; Umamaheshwari, P; Reddy, KP (2019). Quercetin reverses sodium arsenate induced oxidative stress, behavioural and histological alterations in brain of rat. J. Pharm. Sci. \& Res. 11(6): 2267-2274

Naujokas, MF; Anderson, B; Ahsan, H; Aposhian, H; Vasken, G; Joseph, H; Thompson, C;

William, A (2013) "The Broad Scope of Health Effects from Chronic Arsenic Exposure: Update on a Worldwide Public Health Problem". EHP. 121 (3): 295- 302.

Oldereid, N; Thomassen, Y; Attramadal, A (1993).Concentrations of lead, cadmium and zinc in the tissues of reproductive organs of men. $J$ ReprodFertil. 99 (2): 421-425. 
Pant, N; Upadhyay, G; Pandey, S; Mathur, N; Saxena, DK; Srivastava, SP (2003). Lead and cadmium concentration in the seminal plasma of men in the general population: correlation with sperm quality. Reprod Toxicol. 17:447-450

Pant, N; Murthy, RC; Srivastava; SP (2004). Male reproductive toxicity of sodium arsenite in mice. Hum. Exp.Toxicol. 23:399-403

Rafati, RM; Rafati, RM, Kazemi, S; Moghadamnia, AA (2017). Cadmium toxicity and treatment: An update. Caspian J Intern Med. 8(3):135-145.

Ragan, HA; Mast, TJ (1990). Cadmiun inhalation and male reproductive toxicity. Rev.Environ. Contam. Toxicol. 114:1-22

Rani, A; Kumar, A; Lal, A; Pant, M (2014). Cellular mechanisms of cadmium- induced toxicity: a review. Int J Environ Health Res. 24:378-99.

Rajesh, KT; Doreswamy, K; Shrilatha, B; Muralidhara, M (2002).Oxidative stress associated DNA damage in testis of mice: Inductionof abnormal sperms and effects on fertility. Mutation Research. 513:103-111.

Ratnaike, RN (2003). Review: Acute and chronic arsenic toxicity.Postgrad Med J .79:391-396

Ravichandran, R; Rajendran, M; Devapiriam, D (2014). Structural characterization and physicochemical properties of quercetin- $\mathrm{Pb}$ complex. Journal of Coordination Chemistry. 67(8): 1449-1462

Reddy, MVB; Sudheer, SD; Sasikala, P; Reddy, PS; Reddy, SH; Karthik, A (2011). Effect of transplacental and lactational exposure to arsenic on male reproduction in mice. Journal of Reproduction \& Infertility, 2: 41-45.

Renu, K; Madhyastha, H; Madhyastha, R; Maruyama, M; Arunachlam, S; Abilash, V (2017). Role of arsenic exposure in adipose tissue dysfunction and its possibleimplication in diabetes pathophysiology, Toxicol. Lett. 284 86-95

Renu, K; Madhyastha, H; Madhyastha, R; Maruyama, M; Vinayagam, S; Gopalakrishnan, AV (2018). Review on molecular and biochemical insights of arsenic-mediated male reproductive toxicity Life Sciences. 212: 37-58
Roy, CA; Vachhzajani, KD; (1987). Effect of Mercuric Chloride on hydrolytic enzymes of rat testicular tissues. Ind J Expt Biol. 25: 542-547.

Roy, CA; Vachhrajani, KD (1997). Methylmercury induced effect on seminiferous PTM in rats.Ind. $J$ Physiol Allied Sci: 51, 9-15.

Sadik, NA (2008). Effects of diallyl sulfide and zinc on testicular steroidogenesis in cadmium-treated male rats. JBMT 22(5): 345-353.

Sarkar, M;Chaudhuri, GR; Chattopadhyay, A (2003). Effect of sodium arsenite on spermatogenesis, plasma gonadotrohins and testosterone in rats. Asian J. Androl. 5:27-31.

Sengupta, P; Arafa, M; (2019). Hormonal regulation of spermatogenesis. In: Singh R. (ed.). Molecular signaling in spermatogenesis and male infertility. London: CRC Press; 2019.

Singh, P; Chaudhary, S; Patni, A; Sankhla, V (2007). Effect of cadmium chloride induced genotoxicity in bone marrow chromosomes of swiss albino mice and subsequent protective effects of Emblica officinalis and vitamin C. - J. Herb. Med. Toxicol., 1(2): $67-71$

Simons, EN (1968). Guide to Uncommon Metals. Frederick Muller. p. 111.

Siu, ER; Wong, EW; Mruk, DD Sze, KL; Porto, CS; Cheng, CY (2009). An occludin-focal adhesion kinase protein complex at the blood-testis barrier: a study using the cadmium model. Endocrinology. 150:3336-3344

Sharma, P; Aslam K I; Singh, R (2018). Curcumin and Quercetin Ameliorated Cypermethrin and Deltamethrin-Induced Reproductive System Impairment in Male Wistar Rats by Upregulating The Activity of Pituitary-Gonadal Hormones and Steroidogenic Enzymes. Int J fertil steril. 12(1): 72-80.

Shestakova, IG; Radzinsky, VE; Khamoshina, MB (2016). Occult form of premature ovarian insufficiency. Gynecol Endocrinol. 32(2):30-2

Sokol, RZ; Madding, CE; Swerdloff, RS (1985). Lead toxicity and the hypothalamic-pituitary-testicular axis. Biol Reprod. 33:722-728 
Sudha, K (2012). Effect of arsenic induced toxicity in testis of male rats. Indian Journal of Fundamental and Applied Life Sciences. 3: 126-130.

Sule, O; Ayla, A; Osman, A; Hikmet, GU; Hatice, KC; Sunullah, S; Mehmet, C; Yaprak EU; (2018). Evaluation of serum heavy metal levels on primary ovarian insufficiency. Med Science. 7(1):39-42

Tam, P; Liu, W (1985). Gonadal development and fertilityof mice treated prenatally with cadmium duringthe early organogenesis stages. Teratology. 32(3): 453-462

Telisman, S; Cvitkovic, P; Jurasovic, J; Pizent, A; Gavella, M; Rocic, B (2000). Semen quality and reproductive endocrine function in relation to biomarkers of lead, cadmium, zinc, and copper in men. Environ Health Perspect 108:45-53.

Thompson, J; Bannigan, J (2008). Cadmium: toxic effects on the reproductive system and the embryo. Reprod Toxicol. 25(3): 304-315

Thornton, I; Rautiu, R; Brush, SM; (2001). Lead:The Facts. International Lead Association. ISBN 9780-9542496-0-1. Retrieved 5 February 2017.

Ujah, GA; Nna, VU; Agah, MI; Omue, LO; Leku, CB; Osim, EE (2017). Effect of quercetin on cadmium chloride-induced impairments in sexual behaviour and steroidogenesis in male Wistar rats. Andrologia. https://doi.org/10.1111/and.12866

Valko, M; Morris, H; Cronin, MT (2005). Metals, toxicity and oxidative stress. Curr Med Chem. 12:1161-1208.

Wadi, SA; Ahmad, G (1999). Effects of lead on the male reproductive system in mice. $J$ Toxicol Environ Health A. 56 (7):513-21.
Wirth, JJ; Mijal, RS; (2010). Review: Adverse Effects of Low Level HM Exposure on Male Reproductive Function. Special Issue: SBiRM: Focus on Impact of Environmental Toxicants on Reproductive Function. Syst Biol in Reprod Med 56(2), 147-167

Yakubu, MT; Akanji, MA; (2011). Effect of aqueous extract of Massularia acuminata stem on sexual behaviour of male Wistar rats. EvidBased Complement Alternat Med. https://doi.org/10.1155/2011/738103

Yari, A; Sarveazad, A; Asadi, E; Raouf, SJ; Babahajian, A; Amini, N (2016). Efficacy of Crocus sativus L. on reduction of cadmiuminduced toxicity on spermatogenesis in adult rats. Andrologia. DOI: 10.1111/and.12568

Xu, DX; Shen, HM; Zhu, QX; Chua, L; Wang. QN; Chia, SE; Ong, CN (2003). The associations among semen quality, oxidative DNA damage in human spermatozoa and concentrations of cadmium, lead and selenium in seminal plasma. Mutat Res. 534(1-2):155-63.

Xu, W; Bao, H; Liu, F; Liu, L; Zhu, YG; She, J; Dong, S; Cai, M; Li, L; Li, C (2012). Environmental exposure to arsenic may reduce human semen quality: associations derived from a Chinese cross-sectional study. Environ. Health. https://doi.org/10.1186/1476069X-11-46.

Zubair, M; Maqbool, A; Huma, J; Farrah, D (2016). Toxic effects of arsenic on semen and hormonal profile and their amelioration with vitamin $\mathrm{E}$ in Teddy goat bucks. Andrologia, 48, 1220-1228. 